\title{
Zinc adsorption in highly weathered soils
}

\author{
José Carlos Casagrande ${ }^{(1)}$, Marcio Roberto Soares ${ }^{(1)}$ and Ernesto Rinaldi Mouta ${ }^{(1)}$
}

(1)Universidade Federal de São Carlos, Centro de Ciências Agrárias, Departamento de Recursos Naturais e Proteção Ambiental, Rodovia Anhangüera, Km 174, Caixa Postal 153, CEP 13600-970 Araras, SP, Brazil. E-mail: bighouse@power.ufscar.br, mrsoares@cca.ufscar.br, ermouta@cca.ufscar.br

\begin{abstract}
The objective of this work was to assess the effects of $\mathrm{pH}$ and ionic strength upon zinc adsorption, in three highly weathered variable charge soils. Adsorption isotherms were elaborated from batch adsorption experiments, with increasing $\mathrm{Zn}$ concentrations $\left(0-80 \mathrm{mg} \mathrm{L}^{-1}\right)$, and adsorption envelopes were constructed through soil samples reactions with $0.01,0.1$ and $1 \mathrm{~mol} \mathrm{~L}^{-1} \mathrm{Ca}\left(\mathrm{NO}_{3}\right)_{2}$ solutions containing $5 \mathrm{mg} \mathrm{L}^{-1}$ of $\mathrm{Zn}$, with an increasing $\mathrm{pH}$ value from 3 to 8 . Driving force of reaction was quantified by Gibbs free energy and separation factor. Isotherms were $\mathrm{C}-, \mathrm{H}$ - and $\mathrm{L}$-type and experimental results were fitted to nonlinear Langmuir model. Maximum adsorption ranged from $59-810 \mathrm{mg} \mathrm{kg}^{-1}$, and $\mathrm{Zn}$ affinity was greater in subsoil $\left(0.13-0.81 \mathrm{~L} \mathrm{~kg}^{-1}\right)$ than in the topsoil samples $\left(0.01-0.34 \mathrm{~L} \mathrm{~kg}^{-1}\right)$. Zinc adsorption was favorable and spontaneous, and showed sharply increase $(20-90 \%)$ in the 4-6 $\mathrm{pH}$ range. No effect of ionic strength was observed at $\mathrm{pH}$ values below 5 , because specific adsorption mechanisms predominated in the 3-5 $\mathrm{pH}$ range. Above $\mathrm{pH}$ 5, and in subsoil samples, $\mathrm{Zn}$ was adsorbed by electrostatic mechanisms, since ionic strength effect was observed. Despite depth and ionic strength effects, $\mathrm{Zn}$ adsorption depends mainly on the $\mathrm{pH}$.
\end{abstract}

Index terms: $\mathrm{pH}$, adsorption envelope, adsorption isotherm, ionic strength, trace element.

\section{Adsorção de zinco em solos altamente intemperizados}

\begin{abstract}
Resumo - O objetivo deste trabalho foi avaliar o efeito do $\mathrm{pH}$ e da força iônica sobre a adsorção de zinco, em três solos altamente intemperizados, com predomínio de cargas variáveis. A partir de experimentos tipo "batch", foram elaboradas isotermas de adsorção, com quantidades crescentes de $\mathrm{Zn}\left(0-80 \mathrm{mg} \mathrm{L}^{-1}\right)$, e envelopes de adsorção foram feitos pela reação de amostras de terra com soluções de $\mathrm{Ca}\left(\mathrm{NO}_{3}\right)_{2} 0,01,0,1$ e $1 \mathrm{~mol} \mathrm{~L}^{-1}$ e $5 \mathrm{mg} \mathrm{L}^{-1}$ de $\mathrm{Zn}$, submetidas a variações de $\mathrm{pH}$ (3-8). A força direcional da reação de adsorção de $\mathrm{Zn}$ foi estimada pela energia livre de Gibbs e pelo fator de separação. As isotermas foram do tipo C, $\mathrm{He} \mathrm{L}$, e os resultados experimentais ajustaram-se ao modelo de Langmuir. A adsorção máxima variou de 59 a $810 \mathrm{mg} \mathrm{kg}^{-1}$, e o coeficiente de afinidade foi maior em subsuperfície $\left(0,13-0,81 \mathrm{~L} \mathrm{~kg}^{-1}\right)$ do que em superfície $\left(0,01-0,34 \mathrm{~L} \mathrm{~kg}^{-1}\right)$. A adsorção de Zn foi favorável e espontânea, e mostrou nítido aumento (20-90\%) no intervalo de $\mathrm{pH}$ entre 4 e 6 . Não houve efeito da força iônica nos valores de $\mathrm{pH}$ abaixo de 5 , o que indica o predomínio de mecanismos de adsorção específica na faixa de pH 3-5. Acima de $\mathrm{pH} 5$ e no subsolo, o Zn foi adsorvido por mecanismos eletrostáticos, já que foi observado efeito da força iônica. Apesar dos efeitos da profundidade e da força iônica, a adsorção de $\mathrm{Zn}$ depende principalmente do $\mathrm{pH}$.
\end{abstract}

Termos para indexação: pH, envelope de adsorção, isoterma de adsorção, força iônica, elemento-traço.

\section{Introduction}

Zinc $(\mathrm{Zn})$ is an internal transition heavy metal that enters the environment as a result of both natural and anthropogenic activities. Concentrations of $\mathrm{Zn}$ released into the soil by natural pedogenic process are largely related to origin and nature of parent material. Generally, $\mathrm{Zn}$ concentration range of noncontaminated soils varies from 10 to $300 \mathrm{mg} \mathrm{kg}^{-1}$ soil (Ohnesorge \& Wilhelm, 1991). In highly weathered soils, $\mathrm{Zn}$ natural reserve is very low and its deficiency has imposed several limitations on the absolute development of economically important crops in the intertropical zone (Takkar \& Walker, 1993). In plants, $\mathrm{Zn}$ acts as a catalyzing component of more than 300 enzymes, and it is necessary for triptophane, a precursor amino acid of indoleacetic acid (IAA), a growth promoting plant hormone (Mengel \& Kirkby, 2001).

The increase in $\mathrm{Zn}$ redistribution rates among the different compartments of the ecosystem results mainly 
from anthropogenic sources, derived from atmospheric emissions, improper application of agricultural chemicals, or from soil use as the final receiver of sewage sludge and domestic and industrial waste waters. This has created an increase in the quantity of $\mathrm{Zn}$ released in the soil, and increased its potential for entrance in the food chain in toxic concentration, either by plant absorption or through leaching to the groundwater (Covelo et al., 2004; Arias et al., 2005).

Interest has recently grown in the phenomena of metallic ion adsorption by surfaces with $\mathrm{pH}$-dependent charges, in order to understand the role of these contaminants in tropical ecosystems, from the agricultural, environmental and public health points of view. In a complex system such as the soil, especially those contaminated by heavy metals, chemical and also mineralogical properties regulate the speciation, mobility and bioavailability of these contaminants (Covelo et al., 2004). Colloidal constituents, typical of soils with variable charges, such as kaolinite, Fe, and $\mathrm{Al}$ oxy(hydr)oxides have been indicated as the components responsible for the chemical behavior of $\mathrm{Zn}$ in this medium (Düker et al., 1995). These mineral surfaces base several phenomena, especially adsorption, which occurs at the solid-solution interface and is influenced by soil solution properties, such as the $\mathrm{pH}$ and ionic strength (I) (Naidu et al., 1994; Casagrande et al., 2004).

The $\mathrm{pH}$ is the primary factor that governs adsorption and the heavy metal availability, due to alteration in the metal species in solution and to definition of the net charge in adsorption surface (McBride \& Blasiak, 1979; Kuo \& Baker, 1980; Harter, 1983; Machado \& Pavan, 1987; Casagrande et al., 2004). Studies related to the ionic strength are appropriate to understand the stability, nature and intensity of the metal adsorption phenomenon, because they allow the distinction between specific and electrostatic mechanisms (Shuman, 1986; Naidu et al., 1994; Pierangeli et al., 2003), which are not yet fully understood for $\mathrm{Zn}$.

Adsorption isotherms have been widely used in studies on adsorption phenomena, supplying numerical parameters that inform about the retention capacity and the intensity in which the metal is retained by the soil (Hinz, 2001). Langmuir isotherm has been shown to be suitable for Zn adsorption studies (Pombo \& Klamt, 1986; Machado \& Pavan, 1987; Cunha et al., 1994; Nascimento \& Fontes, 2004; Arias et al., 2005). However, metal adsorption modeling in tropical soils is rarely accompanied by a more detailed approach based on thermodynamics, which can serve as measure of the extension and spontaneity of the adsorption reaction (Silveira et al., 1999; Dias et al., 2003; Soares et al., 2005).

While there have been numerous studies on the nature of $\mathrm{Zn}$ interactions with pure mineral systems or with soils from temperate regions (Shuman, 1986; Düker et al., 1995; Covelo et al., 2004), few reports have been devoted to studying these reactions with variable charge soils (Casagrande et al., 2004). Considering the interest in understanding $\mathrm{Zn}$ adsorption phenomenon in soils with variable charges, and the growing search for sustainable strategies that respect the multifunctionality of the soil, the objectives of this study were to investigate the influence of $\mathrm{pH}$ and ionic strength on $\mathrm{Zn}$ adsorption reaction by highly weathered variable charge soils.

\section{Materials and Methods}

Topsoil (0.0-0.2 m) and subsoil (diagnostic B horizon) samples were collected from two acric Oxisols [heavy clayey-textured Anionic "Rhodic" Acrudox (RA) and medium-textured Anionic "Xanthic" Acrudox (XA)], and of an Alfisol [heavy clayey-textured Rhodic Hapludalf (RH)] (Soil Survey Staff, 1999), derived from basalt, in two locations in the State of São Paulo, Brazil (Ribeirão Preto $-21^{\circ} 10^{\prime} \mathrm{S}, 47^{\circ} 48^{\prime} \mathrm{W}$; Guaíra $-20^{\circ} 19^{\prime} \mathrm{S}, 48^{\circ} 18^{\prime} \mathrm{W}$ ).

Chemical, physical and mineralogical characterization of the samples was performed according to Camargo et al. (1986) and Raij et al. (2001). Additionally, samples were investigated using the cesium adsorption method, which measures both permanent and variable charges and is based on the preference of $\mathrm{Cs}^{+}$over $\mathrm{Li}^{+}$in the siloxane surface sites, and on the lower selectivity of ionizable surface group for the Cs ion (Weber et al., 2005). Some properties of the soil samples are given in Table 1.

Laboratory batch mode adsorption experiments were carried out after adding $20 \mathrm{~mL} \mathrm{Ca}\left(\mathrm{NO}_{3}\right)_{2}$ electrolytic solution, containing different initial concentration of $\mathrm{Zn}\left(\mathrm{C}_{0}\right)$ in the form of hydrated nitrate salt $\left[\mathrm{Zn}\left(\mathrm{NO}_{3}\right)_{2} \cdot 4 \mathrm{H}_{2} \mathrm{O}\right]$, at $2 \mathrm{~g}$ of fine air-dried soil samples (1:10 soil:solution ratio). The soil-solution system was placed in polyethylene flasks, under agitation $\left(150\right.$ osc $\left.\mathrm{min}^{-1}\right)$ for 24 hours at $24 \pm 2^{\circ} \mathrm{C}$. The suspension was filtered, and $\mathrm{Zn}$ concentration remaining in the supernatant was determined by atomic absorption spectrophotometry. Adsorption isotherms were elaborated for soil samples at natural $\mathrm{pH}$ from experiments with increasing $\mathrm{Zn}$ concentrations $(0,1,2,5$, 


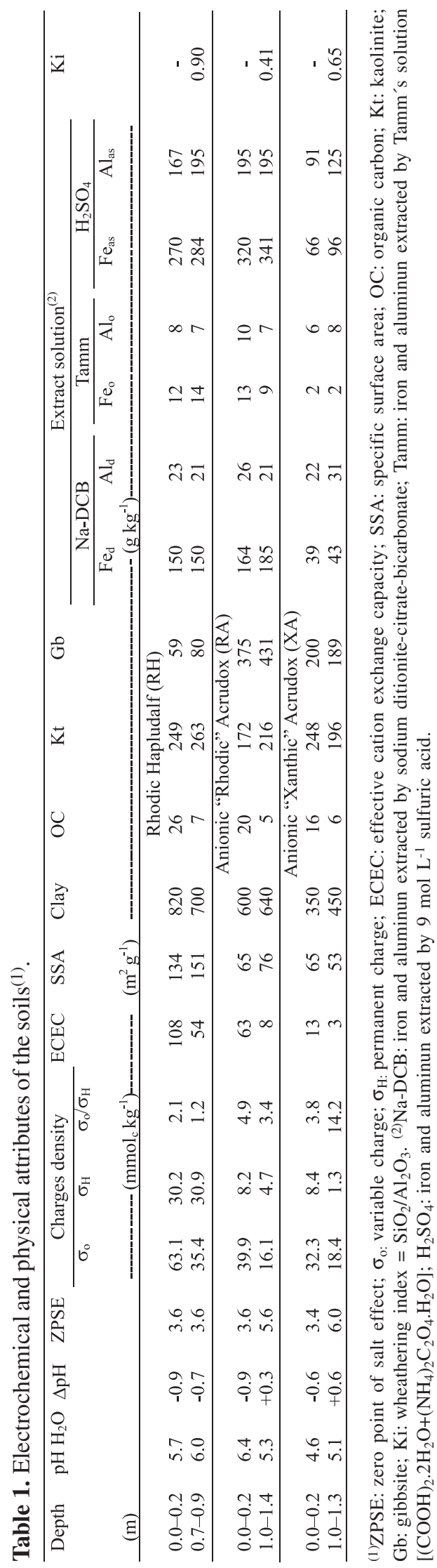

$10,15,20,25,30,40$ and $\left.80 \mathrm{mg} \mathrm{L}^{-1}\right)$, with $0.01 \mathrm{~mol} \mathrm{~L}^{-1}$ $\mathrm{Ca}\left(\mathrm{NO}_{3}\right)_{2}$ as electrolytic support. Under similar experimental conditions, adsorption envelopes were constructed by the $\% \mathrm{Zn}_{\text {ads }}$ vs. $\mathrm{pH}$ plot, after adjusting the $\mathrm{pH}$ by adding $\mathrm{HCl}$ or $\mathrm{NaOH} 4 \mathrm{~mol} \mathrm{~L}^{-1}$ in the suspensions containing $5 \mathrm{mg} \mathrm{L}^{-1} \mathrm{Zn}$ in $\mathrm{Ca}\left(\mathrm{NO}_{3}\right)_{2}$ 0.01, 0.1 and $1 \mathrm{~mol} \mathrm{~L}^{-1}$ electrolyte support, for the simultaneous assessment of the $\mathrm{pH}$ and ionic strength effects on $\mathrm{Zn}$ adsorption reaction.

The quantity of adsorbed $\mathrm{Zn}\left([\mathrm{Zn}]_{\mathrm{ads}}\right)$ and the adsorption percentage $\left(\% \mathrm{Zn}_{\mathrm{ads}}\right)$ were calculated by the equations $[\mathrm{Zn}]_{\mathrm{ads}}=\left([\mathrm{Zn}]_{0}-[\mathrm{Zn}]_{\mathrm{eq}}\right)(\mathrm{V} / \mathrm{M})$ and $\% \mathrm{Zn}_{\text {ads }}=100\left\{\left([\mathrm{Zn}]_{0}-[\mathrm{Zn}]_{\mathrm{eq}}\right) /[\mathrm{Zn}]_{0}\right\}$, respectively, in which: $[\mathrm{Zn}]_{\mathrm{ads}}$ is the quantity $\left(\mathrm{mg} \mathrm{kg}^{-1}\right)$ of $\mathrm{Zn}$ adsorption after equilibrium; $[\mathrm{Zn}]_{0}$ and $[\mathrm{Zn}]_{\mathrm{eq}}$ are the initial added and the equilibrium concentrations $\left(\mathrm{mg} \mathrm{L}^{-1}\right)$, respectively; $\mathrm{V}$ is the solution volume $(\mathrm{mL}) ; \mathrm{M}$ is the mass of soil sample $(\mathrm{g})$. All determinations were run in triplicate.

Adsorption isotherms ([Zn $]_{\text {ads }}$ vs. $[\mathrm{Zn}]_{\text {eq }}$ ) were constructed, and the $\mathrm{Zn}$ adsorption was compared with that estimated by the nonlinear form of Langmuir isotherm $[\mathrm{Zn}]_{\mathrm{ads}}=\operatorname{Ads}_{\max }\left(\mathrm{K}_{\mathrm{L}}[\mathrm{Zn}]_{\mathrm{eq}} / 1+\mathrm{K}_{\mathrm{L}}[\mathrm{Zn}]_{\mathrm{eq}}\right)$, in which: $\mathrm{K}_{\mathrm{L}}$ is the parameter related to the soil affinity for $\mathrm{Zn}\left(\mathrm{L} \mathrm{kg}^{-1}\right)$; $\mathrm{Ads}_{\max }$ is the maximum $\mathrm{Zn}$ adsorption capacity $\left(\mathrm{mg} \mathrm{kg}^{-1}\right)$. The Langmuir isotherm was fitted by the Fitfunc and Fitfun.bas softwares (Barrow, 1987), which used the nonlinear optimization of the least squares and did not require the linearization of the isotherm, which avoided both the introduction of changes in the error distribution and acquisition of influenced parameters. Preliminary data concerning the degree of development and spontaneity of the adsorption reaction was obtained from assessing the equilibrium parameter or the $K_{R}$ separation factor, a dimensionless constant that indicates whether the adsorption reaction was favorable by the ratio $\mathrm{K}_{\mathrm{R}}=1 /\left(1+\mathrm{K}_{\mathrm{L}} \mathrm{C}_{0}\right)$, in which: $\mathrm{K}_{\mathrm{L}}$ is the affinity constant, estimated by the Langmuir equation (Ho et al., 2002; Singh \& Pant, 2004; Soares et al., 2005). The spontaneity of adsorption reactions was also described mathematically by determining the Gibbs free energy $\Delta \mathrm{G}=\mathrm{RT}\left(\log \mathrm{C}_{\mathrm{eq}}-\log \mathrm{C}_{0}\right)$, in which: $\Delta \mathrm{G}$ is the variation in the free energy $\left(\mathrm{J} \mathrm{mol}^{-1}\right)$; $\mathrm{R}$ is the universal constant of the gases $\left(8.314 \mathrm{~J} \mathrm{~mol}^{-1} \mathrm{~K}^{-1}\right)$; $\mathrm{T}$ is the absolute temperature (K) (Silveira et al., 1999; Dias et al., 2003; Soares et al., 2005). 


\section{Results and Discussion}

Adsorption isotherms for weathered soils, at natural $\mathrm{pH}$ and at constant ionic strength $\left[0.01 \mathrm{~mol} \mathrm{~L}^{-1}\right.$ $\left.\mathrm{Ca}\left(\mathrm{NO}_{3}\right)_{2}\right]$, showed increase in $\mathrm{Zn}$ adsorption with the increase in the initial concentration (Figure 1). The isotherm shape was characteristic for each sample and exhibited different $\mathrm{Zn}$ adsorption pattern, evaluated according to the classification proposed by Giles et al. (1974). Zinc adsorption by the Anionic "Xanthic" Acrudox, and by Anionic "Rhodic" Acrudox topsoil samples was best represented by C-type isotherms $(\mathrm{C}=$ constant $)$, with a constant slope along the $\mathrm{Zn}$ concentration range. This type of isotherm was not expected, because it shows that the availability of sites for adsorption remained constant, regardless of the initial $\mathrm{Zn}$ concentration. A very similar shape was observed for the Rhodic Hapludalf topsoil sample, with strong initial slope characterizing H-type isotherm, as a result of the strong interaction with soil particles. Casagrande et al. (2004) reported that $\mathrm{Zn}$ adsorption by topsoil and subsoil samples from a Brazilian acric Oxisol was adequately represented by $\mathrm{H}$-type isotherms, when $\mathrm{pH}$ was close to 7. Agbenin \& Olojo (2004) reported that Zn adsorption by samples from the topsoil of an Alfisol also produced H-type isotherms.

The L-type isotherm, characterized by decrease in adsorption as the adsorption surface becomes saturated, was more common for subsoil samples. With the increase in the saturation level, the colloidal surface may become completely covered after the formation of a monomolecular layer of the adsorbate, and the isotherm assumes an asymptotic performance, such as that observed for the two Oxisols. In the subsoil, the affinity of Rhodic Hapludalf for the adsorbate decreased after the additions of high initial $\mathrm{Zn}$ concentrations, when the isotherm manifested the L-type performance. However, not even the greatest quantity of $\mathrm{Zn}$ added could saturate the sites to the point of causing the surface covering and, thus, the asymptote was not observed.

Langmuir equation adequately simulated the experimental $\mathrm{Zn}$ adsorption results, as reported previously (Cunha et al., 1994; Casagrande et al., 2004; Nascimento \& Fontes, 2004). Experimental results obtained for Rhodic Hapludalf showed greater adherence to the Langmuir isotherm. The Oxisols showed small deviations between the observed and simulated data with the increase in the $\mathrm{Zn}$ concentration. The maximum adsorption parameter $\left(\mathrm{Ads}_{\max }\right)$ and the affinity constant $\left(\mathrm{K}_{\mathrm{L}}\right)$, indicated that $\mathrm{Zn}$ adsorption varied according to the soil and to the sampling depth. The lowest and highest Ads $_{\max }$ values were verified for Anionic "Rhodic" Acrudox, in the subsoil, and for Rhodic Hapludalf, in the topsoil samples, respectively. The Ads $\max$ values were from 246 to $810 \mathrm{mg} \mathrm{kg}^{-1}$, for the topsoil samples, and from 59 to $789 \mathrm{mg} \mathrm{kg}^{-1}$, in the subsoil. The results were in line with those reported by Pombo \& Klamt (1986) in an Alfisol (698 $\left.\mathrm{mg} \mathrm{kg}^{-1}\right)$, but were less than those reported by Casagrande et al. (2004) in an acric Oxisol $\left(1,362 \mathrm{mg} \mathrm{kg}^{-1}\right)$. The affinity constant $\left(\mathrm{K}_{\mathrm{L}}\right)$ indicated that the $\mathrm{Zn}$ adsorption reaction proceeded more strongly in the subsoil layers.
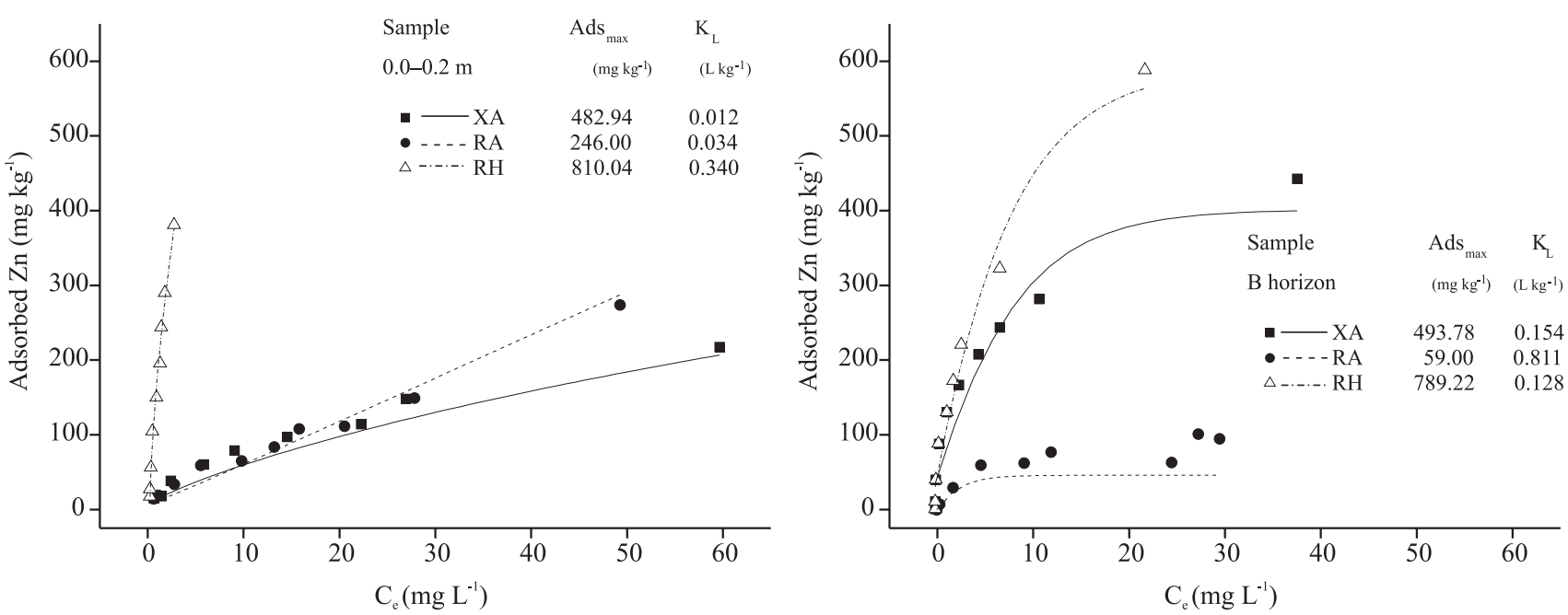

Figure 1. Isotherms of $\mathrm{Zn}$ adsorption (curves) and $\mathrm{Zn}$ adsorption reaction parameters ( $\mathrm{Ads} \mathrm{s}_{\max }$ : maximum adsorption; $\mathrm{K}_{\mathrm{L}}$ : affinity constant), obtained from the fit of the Langmuir equation to the experimental results (points) for the Anionic "Xanthic" Acrudox (XA), Anionic “Rhodic” Acrudox (RA) and Rhodic Hapludalf (RH). 
There was strong dependence on $\mathrm{Zn}$ adsorption in relation to the $\mathrm{pH}$, regardless of the soil or sampling depth. Zinc adsorption increased drastically with the increase in $\mathrm{pH}$, varying from 20 to $90 \%$ in a small $\mathrm{pH}$ interval (from 4 to 6). In fact, there is a critical interval for solidsolution interfaces, generally less than two $\mathrm{pH}$ units, where the metal adsorption percentage can increase clearly from an extremely low value, at low $\mathrm{pH}$, to up to $100 \%$, at high $\mathrm{pH}$ values. This critical interval, known as the adsorption edge, is graphically represented in the adsorption envelopes (Sposito, 1984) (Figure 2). Harter (1983) reported that metal adsorption was $\mathrm{pH}$-dependent and that the intensity of the phenomena increased drastically above 7 . Rhodic Hapludalf adsorbed more than $80 \%$ at $\mathrm{pH} 4.5$ and $50 \%$ at $\mathrm{pH} 3.5$, in the topsoil and subsoil samples, respectively. Zinc was adsorbed at lower $\mathrm{pH}$ values of the Rhodic Hapludalf samples, probably as a result of the manifestation of permanent charges that did not depend on the $\mathrm{pH}$ variation (Table 1). However, $\mathrm{Zn}$ adsorption can be reduced at low $\mathrm{pH}$ values due to competition with the cations from the support electrolyte for exchange sites (McBride \& Blasiak, 1979). The occurrence of $\mathrm{Zn}$ adsorption - even at $\mathrm{pH}$ values below zero point of salt effect (ZPSE) (Table 1) - was also attributed to the manifestation of specific adsorption mechanisms, especially in the case of the Oxisols (Kuo \& Baker, 1980).

Approximately $20 \%$ of $\mathrm{Zn}$ was adsorbed immediately at $\mathrm{pH} 3$ in all the subsoil samples. Soil pH is the main factor that determines $\mathrm{Zn}$ adsorption, because it is related to the hydrolysis constant of the metal ions (Harter, 1983;
Covelo et al., 2004). Practically all the added $\mathrm{Zn}\left(5 \mathrm{mg} \mathrm{L}^{-1}\right)$ disappeared from the soil solution, when the $\mathrm{pH}$ was about 7 , regardless of the soil or depth. Naidu et al. (1994) studied highly weathered soils dominated by sesquioxides, and reported $100 \%$ metal adsorption when the $\mathrm{pH}$ was greater than 6 . This occurred at high $\mathrm{pH}$ values, because the value of $\mathrm{Zn}$ first hydrolysis constant $\left(\mathrm{pKa}_{1}\right)$ is around 9.

At the highest $\mathrm{pH}$ values obtained in this study, the presence of the $\mathrm{ZnOH}^{+}$species was suggested, while the $\mathrm{Zn}(\mathrm{OH})_{2}{ }^{0}$ species was considered of limited occurrence. The $\mathrm{ZnOH}^{+}$species concentration increase tenfold at each increase in $\mathrm{pH}$ unit and, since $\mathrm{ZnOH}^{+}$ performs as a monovalent ion, the energetic barrier that must be overcome, when it comes closer to the surface of the particle, is smaller than in the case of the $\mathrm{Zn}^{2+}$ ion. Furthermore, the quantity of adsorption sites with greater affinity for $\mathrm{Zn}$ increase with the rise in $\mathrm{pH}$ (Casagrande et al., 2004).

The proportion of adsorbed metal ions increased uniformly and continuously with the increase in $\mathrm{pH}$, but the shape of the curve and the position of the adsorption edges depended on the soil identity, especially concerning its mineralogical constitution. The adsorption pattern was very similar for the Oxisol samples, as showed by the shape and overlapping positioning of the adsorption edges. The adsorption edges that represented $\mathrm{Zn}$ adsorption by the Oxisols presented typical sigmoid shape, with characteristic S-type adsorption curve especially regarding their positioning. In these soils, $\mathrm{Zn}$ retention was characterized initially by a small slope in the $\mathrm{pH}$
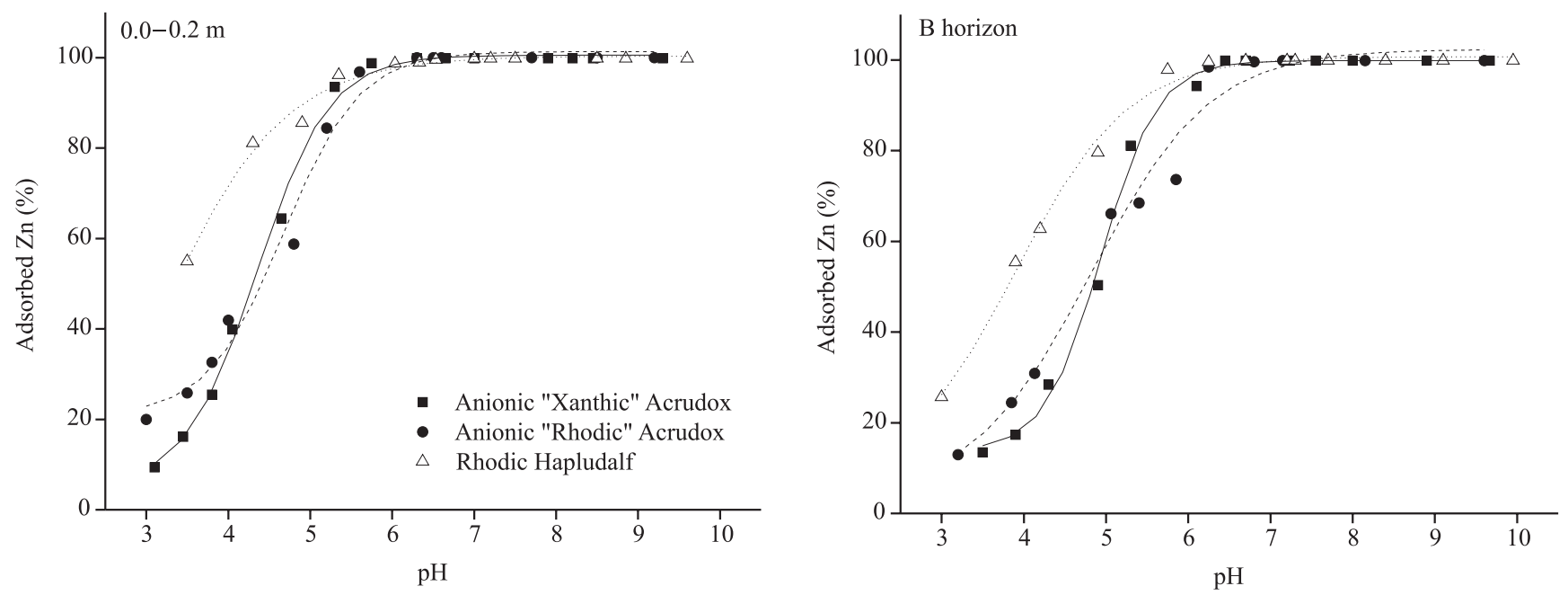

Figure 2. Zinc adsorption envelopes for topsoil and subsoil samples from highly weathered tropical soils. 
range between 3 and 4, both on the topsoil and at depth, when about 10 to $20 \% \mathrm{Zn}$ was adsorbed. The atypical shape of the Rhodic Hapludalf adsorption edge suggested that $\mathrm{Zn}$ adsorption was qualitatively different, when compared to the Oxisols. The adsorption edge is a function of the affinity of a given type of adsorption surface, and it is normally argued that this affinity is high, when adsorption occurs at low $\mathrm{pH}$ values (Harter, 1983), as verified for Rhodic Hapludalf.

The $K_{R}$ values were between 0 and 1 for all the samples (Figure 3). Following a simplified approach (Singh \& Pant, 2004; Soares et al., 2005), adsorption is favorable and spontaneous when $K_{R}<1$, while values of $K_{R}>1$ indicate absence of spontaneity in the reaction. The $K_{R}$ coefficient can further indicate whether the adsorption isotherm is unfavorable to the process $\left(K_{R}>1\right)$, linear $\left(K_{R}=1\right)$, favorable $\left(0<K_{R}<1\right)$ or irreversible $\left(K_{R}=0\right)$ (Ho et al., 2002). Thereby, the $K_{R}$ values showed that the adsorption reaction was spontaneous and favorable, regardless of sampling depth. The lower $K_{R}$ values were obtained for the higher $\mathrm{Zn}$ quantities added. This indicated that the adsorption reaction was more favorable at the higher initial concentrations $\left(\mathrm{C}_{0}\right)$, indicating further that all the soils were efficient systems for $\mathrm{Zn}$ retention, even with some variations in consequence of depth in the following soil sequence: $\mathrm{RH}>\mathrm{XA}>\mathrm{RA}$ on the topsoil, and $\mathrm{RA}>\mathrm{XA} \cong \mathrm{RH}$ in the subsoil. High and constant $K_{R}$ values close to 1 indicated that $\mathrm{Zn}$ adsorption by the Anionic "Rhodic" Acrudox topsoil samples was less favored or spontaneous. In contrast, the spontaneity of the $\mathrm{Zn}$ adsorption reaction was drastically increased in the subsoil samples. This performance indicated that $\mathrm{Zn}$ adsorption developed more spontaneously in the absence of organic material, especially in the Oxisols, ratifying data obtained from the affinity constant $\left(\mathrm{K}_{\mathrm{L}}\right)$ (Figure 1). For Rhodic Hapludalf, the separation factor was not a very sensitive parameter for sampling depth, probably because the soil has a more reactive mineralogy, and its electric charge of permanent nature is less influenced by the organic matter.

The Gibbs free energy $(\Delta \mathrm{G})$ is a measure of the extension or force that guides the adsorption reaction (Soares et al., 2005). The $\Delta \mathrm{G}$ values were negative and confirmed the feasibility and spontaneity of $\mathrm{Zn}$ adsorption (Figure 4), with energy released for conversion of the less stable $\mathrm{Zn}$ forms in solution to adsorbed forms with greater stability. Similar results were reported for $\mathrm{Cd}$ (Dias et al., 2003) and Cu (Silveira et al., 1999) adsorption by highly weathered soils. Regardless of soil or sampling depth, $\Delta \mathrm{G}$ values increased with the $\mathrm{pH}$, indicating that the phenomenon became more thermodynamically spontaneous with this increase. Also with the increase in $\mathrm{pH}$, the $\Delta \mathrm{G}$ became more negative implicating an increase in the driving force for the adsorption reaction to take place.

At $\mathrm{pH}$ less than 5, $\mathrm{Zn}$ adsorption was most favored in the Rhodic Hapludalf topsoil sample. Probably, the higher organic matter and clay contents, combined with a greater specific surface offered by the phyllosilicates of 2:1 type, still present in Rhodic Hapludalf (Table 1), may have optimized the contact between the metal cations
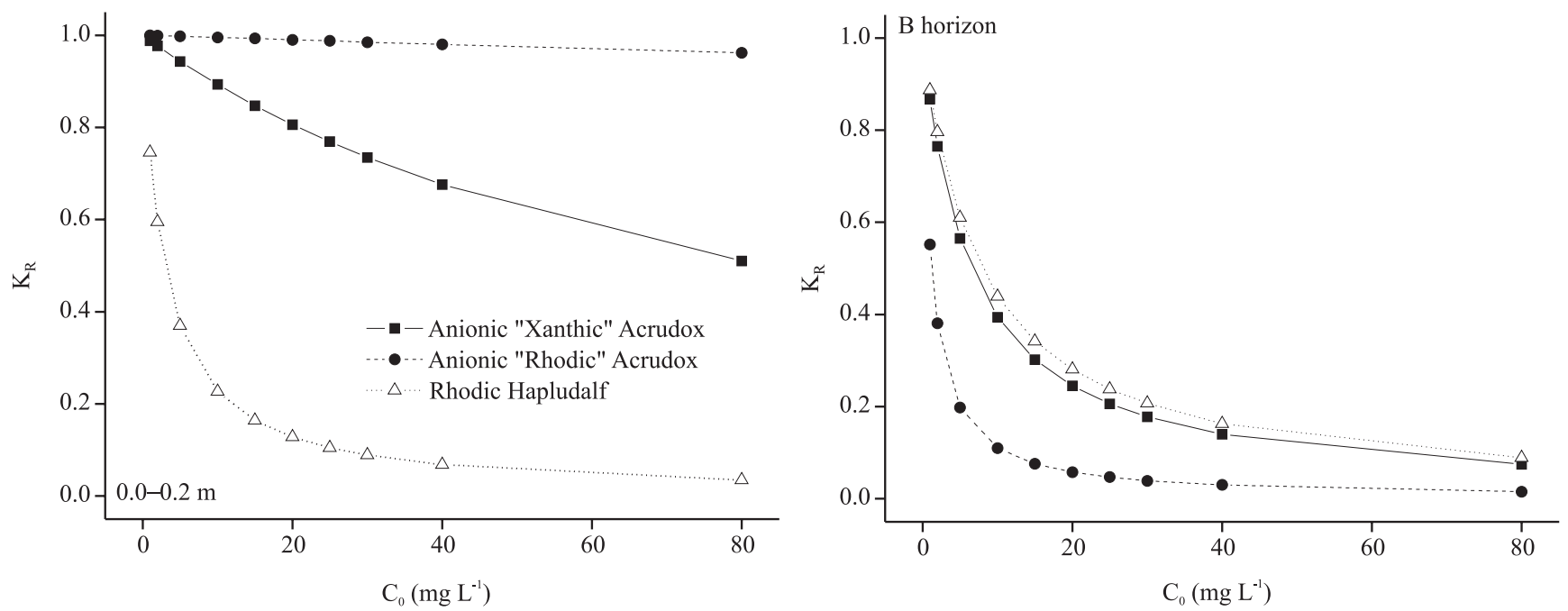

Figure 3. Variations in the separation factor values $\left(\mathrm{K}_{\mathrm{R}}\right)$ in function of $\mathrm{Zn}$ concentration added $\left(\mathrm{C}_{0}\right)$ to soils, at natural $\mathrm{pH}$. 

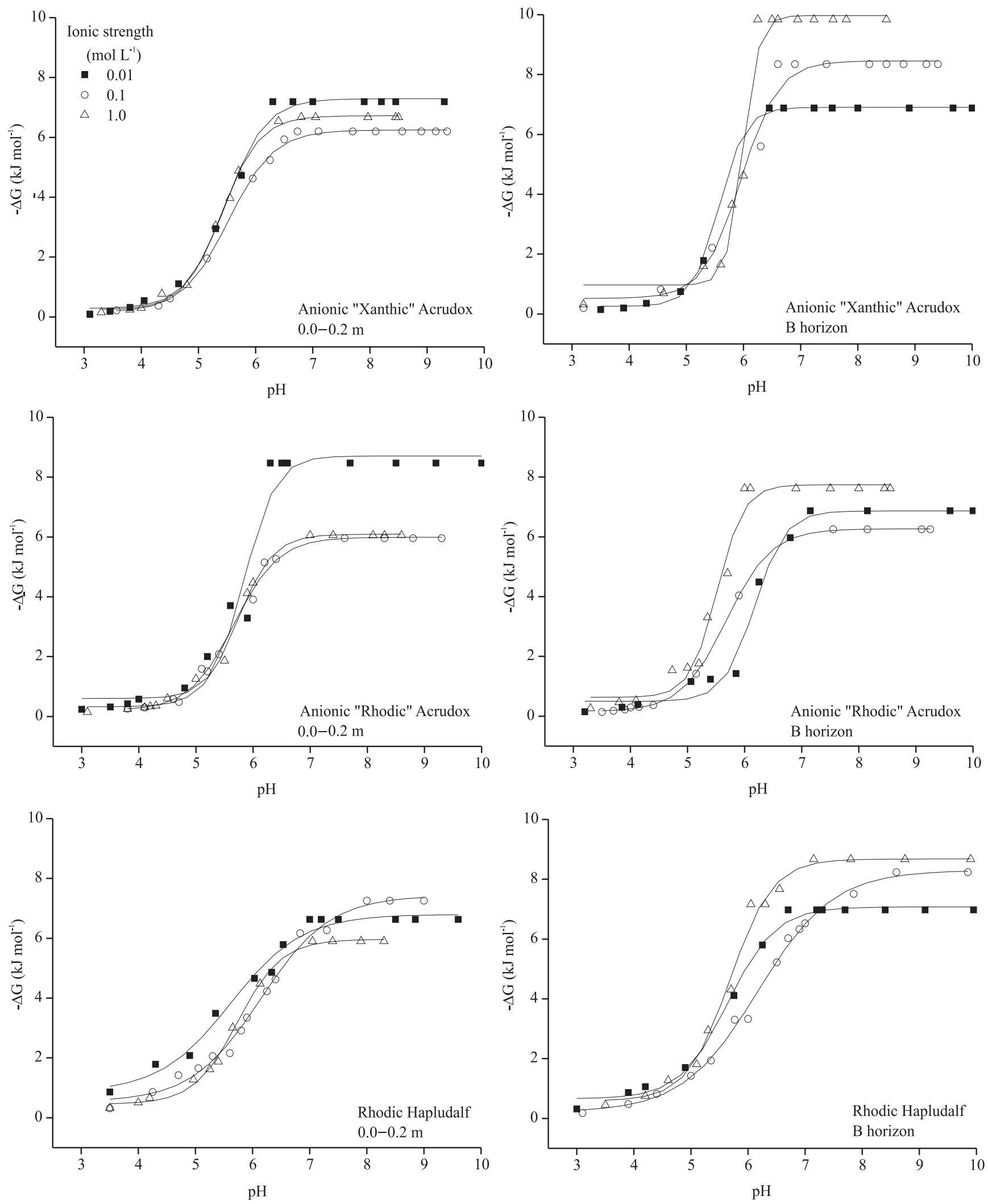

Figure 4. Effect of the variation in soil solution parameters (pH and ionic strength) on the variation of free energy $(\Delta \mathrm{G})$ of $\mathrm{Zn}$ adsorption reaction by weathered soils. 
present in solution and the surface of the solid phase. In the Oxisols, low $\mathrm{pH}$ values (3-5) did not cause significant increases in $\Delta \mathrm{G}$ values. However, a clear increase in the $\Delta \mathrm{G}$ of $\mathrm{Zn}$ adsorption by Anionic "Rhodic" Acrudox and by Anionic "Xanthic" Acrudox occurred in the $\mathrm{pH}$ interval between 5 and 6.5 .

Zinc adsorption was also evaluated, regarding alterations in the electrolyte support concentration, using $\Delta \mathrm{G}$ as the numerical parameter for the reaction.

No effect of ionic strength was observed in the $\Delta \mathrm{G}$ values for $\mathrm{Zn}$ adsorption at $\mathrm{pH}$ values below 5 . However, starting at this value, its effect depended on the depth. Zinc can be adsorbed either by electrostatic mechanisms or specific mechanisms on $\mathrm{Fe}$ and $\mathrm{Al}$ oxy(hydr)oxides surfaces (Arias et al., 2005). However, inner-sphere type complex formation has been shown to be the most frequently occurring mechanism, and ions that are specifically adsorbed are less influenced by variation in the ionic strength (Shuman, 1986). The maximum variation in the $\mathrm{Zn}$ adsorption free energy $\left(\Delta \mathrm{G}_{\max }\right)$ also depended on the $\mathrm{pH}$ (Table 2). The $\mathrm{Zn}$ adsorption reaction by the Oxisols and Alfisol samples, at ionic strength $0.01 \mathrm{~mol} \mathrm{~L}^{-1} \mathrm{Ca}\left(\mathrm{NO}_{3}\right)_{2}$, reached a maximum spontaneity close to $\mathrm{pH} 6$ and 7, respectively. The increase in the electrolytic support concentration caused a variation in $\mathrm{pH}$ values, where $\Delta \mathrm{G}_{\max }$ was reached in the Anionic "Rhodic" Acrudox and Rhodic Hapludalf samples. In the topsoil samples, the $\Delta \mathrm{G}_{\max }$

Table 2. Maximum variation in the free energy $\left(\Delta \mathrm{G}_{\max }\right)$ of the $\mathrm{Zn}$ adsorption reaction, in function of $\mathrm{pH}$ and ionic strength.

\begin{tabular}{lcccc}
\hline Soil & $\begin{array}{c}\text { Sampling } \\
\text { depth } \\
(\mathrm{m})\end{array}$ & $\begin{array}{c}\text { Ionic } \\
\text { strength } \\
\left(\mathrm{mol} \mathrm{L}^{-1}\right)\end{array}$ & $\Delta \mathrm{G}$ & $\mathrm{pH}$ \\
$\left(\mathrm{J} \mathrm{mol}^{-1}\right)$ & \\
\hline Rhodic Hapludalf & $0.0-0.2$ & 0.01 & $-6,640$ & 7.0 \\
& & 0.1 & $-7,260$ & 8.0 \\
& $0.7-0.9$ & 1.0 & $-5,900$ & 7.0 \\
& & 0.01 & $-6,980$ & 7.0 \\
& & 0.1 & $-8,235$ & 8.5 \\
& & 1.0 & $-8,675$ & 7.0 \\
\hline Anionic "Rhodic" Acrudox & $0.0-0.2$ & 0.01 & $-8,470$ & 6.0 \\
& & 0.1 & $-5,960$ & 7.5 \\
& & 1.0 & $-6,060$ & 7.0 \\
& $0.7-0.9$ & 0.01 & $-6,870$ & 7.0 \\
& & 0.1 & $-6,250$ & 7.0 \\
& & 1.0 & $-7,615$ & 6.0 \\
\hline Anionic "Xanthic" Acrudox & $0.0-0.2$ & 0.01 & $-7,200$ & 6.0 \\
& & 0.1 & $-6,205$ & 6.0 \\
& & 1.0 & $-6,675$ & 6.0 \\
& & & & \\
& $1.0-1.3$ & 0.01 & $-6,880$ & 6.0 \\
& & 0.1 & $-8,350$ & 6.0 \\
& & 1.0 & $-9,840$ & 6.0 \\
\hline
\end{tabular}

decreased with increase in ionic strength, and the greatest values were between -6,640 (Rhodic Hapludalf) and $-8,470 \mathrm{~J} \mathrm{~mol}^{-1}$ (Anionic "Rhodic" Acrudox) (Table 2), at ionic strength $0.01 \mathrm{~mol} \mathrm{~L}^{-1}$ $\mathrm{Ca}\left(\mathrm{NO}_{3}\right)_{2}$. These results corroborated reports by Pierangeli et al. (2003), who attributed the reduction in adsorption with the increase in ionic strength to competition among ions for exchange sites. In contrast, large increases in $\Delta \mathrm{G}_{\max }$ would be observed, when ionic strength increased on the subsoil samples. At the electrolytic support concentration of $1 \mathrm{~mol} \mathrm{~L}^{-1}$, the variation of $\Delta \mathrm{G}_{\max }$ values was between -7,615 (Anionic "Rhodic" Acrudox) and -9,840 $\mathrm{J} \mathrm{mol}^{-1}$ (Anionic "Xanthic" Acrudox). This fact may have occurred because of the inorganic fraction greater exposure to reactions involving inner sphere-type mechanisms (Düker et al., 1995), that is, of greater energy.

\section{Conclusions}

1. Langmuir equation adequately simulates the experimental results of adsorbed $\mathrm{Zn}$, and the model can be used to prognosticate $\mathrm{Zn}$ performance in soils with similar attributes to those in this study.

2. $\mathrm{Zn}$ adsorption depends, mainly, on the $\mathrm{pH}$.

3. Greater adsorption capacity can be reached in the topsoil layers, but $\mathrm{Zn}$ affinity in subsoil is larger, especially in response to alterations in the $\mathrm{pH}$.

4. In the subsoil, $\mathrm{Zn}$ adsorption reaction is stronger.

5. At $\mathrm{pH}$ values below 5, ionic strength have no effect on $\mathrm{Zn}$ adsorption; from $\mathrm{pH}$, $\mathrm{Zn}$ adsorption decrease, with increase in ionic strength, and this effect allows to distinguish specific and eletrostatic $\mathrm{Zn}$ adsorption mechanisms.

\section{Acknowledgements}

To Fundação de Amparo à Pesquisa do Estado de São Paulo, for financial support.

\section{References}

AGBENIN, J.O.; OLOJO, L.A. Competitive adsorption of copper and zinc by a Bt horizon of a savanna Alfisol as affected by $\mathrm{pH}$ and selective removal of hydrous oxides and organic matter. Geoderma, v.119, p.85-95, 2004.

ARIAS, M.; PÉREZ-NOVO, C.P.; OSORIO, F.; LÓPEZ, E.; SOTO, B. Adsorption and desorption of copper and zinc in the surface layer of acid soils. Journal of Colloid and Interface Science, v.288, p.21-29, 2005. 
BARROW, N.J. Reactions with variable-charge soils. Dordrecth: Martinus Nijhoff Publishers, 1987. 191p.

CAMARGO, O.A.; MONIZ, A.C.; JORGE, J.A.; VALADARES, J.M.A.S. Métodos de análise química, mineralógica e física de solos do Instituto Agronômico de Campinas. Campinas: IAC, 1986. 94p. (Boletim Técnico, 106).

CASAGRANDE, J.C.; ALLEONI, L.R.F.; CAMARGO, O.A.; ARNONE, A.D. Effects of $\mathrm{pH}$ and ionic strength on zinc sorption by a variable charge soil. Communications in Soil Science and Plant Analysis, v.35, p.2087-2095, 2004.

COVELO, E.F.; ÁLVAREZ, N.; ANDRADE COUCE, M.L.; VEGA, F.A.; MARCET, P. Zn adsorption by different fractions of Galician soils. Journal of Colloid and Interface Science, v.280, p.343349, 2004.

CUNHA, R.C.A.; CAMARGO, O.A.; KINJO, T. Aplicação de três isotermas na adsorção de zinco em Oxissolos, Alfissolos e Ultissolos. Revista Brasileira de Ciência do Solo, v.18, p.15-20, 1994.

DIAS, N.M.P.; ALLEONI, L.R.F.; CASAGRANDE, J.C.; CAMARGO, O.A. Energia livre da reação de adsorção de cádmio em Latossolos ácricos. Ciência Rural, v.33, p.829-834, 2003.

DÜKER, A.; LEDIN, A.; KARLSSON, S.; ALLARD, B. Adsorption of zinc on colloidal (hydr)oxides of $\mathrm{Si}, \mathrm{Al}$ and $\mathrm{Fe}$ in the presence of a fulvic acid. Applied Geochemistry, v.10, p.197-205, 1995.

GILES, C.H.; SMITH, D.; HUITSON, A. A general treatment and classification of the solute adsorption isotherm. I. Theoretical. Journal of Colloid and Interface Science, v.47, p.755-765, 1974.

HARTER, R.D. Effect of soil pH on adsorption of lead, copper, zinc, and nickel. Soil Science Society of America Journal, v.47, p.47-51, 1983.

HINZ, C. Description of sorption data with isotherm equations. Geoderma, v.99, p.225-243, 2001.

HO, Y.S.; HUANG, C.T.; HUANG, H.W. Equilibrium sorption isotherm for metal ions on tree fern. Process Biochemistry, v.37, p.1421-1430, 2002.

KUO, S.; BAKER, A.S. Sorption of copper, zinc, and cadmium by some acid soils. Soil Science Society of America Journal, v.44, p.969-974, 1980.

MACHADO, P.L.O.A.; PAVAN, M.A. Adsorção de zinco por alguns solos do Paraná. Revista Brasileira de Ciência do Solo, v.11, p.353-356, 1987.

McBRIDE, M.B.; BLASIAK, J.J. Zinc and copper solubility as a function of $\mathrm{pH}$ in an acid soil. Soil Science Society of America Journal, v.43, p.866-870, 1979.
MENGEL, K.; KIRKBY, E.A. Principles of plant nutrition. $5^{\text {th }}$ ed. Dordrecht: Kluwer Academic Publishers, 2001. 849p.

NAIDU, R.; BOLAN, N.S.; KOOKANA, R.S.; TILLER, K.G. Ionicstrength and $\mathrm{pH}$ effects on surface charge of $\mathrm{Cd}$ sorption characteristics of soils. Journal of Soil Science, v.45, p.419-429, 1994.

NASCIMENTO, C.W.A.; FONTES, R.L.F. Correlação entre características de Latossolos e parâmetros de equações de adsorção de cobre e zinco. Revista Brasileira de Ciência do Solo, v.28, p.965-971, 2004.

OHNESORGE, F.K.; WILHELM, M. Zinc. In: MERIAN, E. (Ed.). Metals and their compounds in the environment. Weinheim: Wiley-VHC, 1991. p.1309-1342.

PIERANGELI, M.A.P.; GUILHERME, L.R.G.; OLIVEIRA, L.R.; CURI, N.; SILVA, M.L.N. Efeito da força iônica da solução de equilíbrio na adsorção de cádmio em Latossolos brasileiros. Pesquisa Agropecuária Brasileira, v.38, p.737-745, 2003.

POMBO, L.C.A.; KLAMT, E. Adsorção de zinco e cobre de dois solos do Estado do Rio Grande do Sul. Revista Brasileira de Ciência do Solo, v.10, p.191-194, 1986. van

RAIJ, B. van; ANDRADE, J.C.; CANTARELLA, H.; QUAGGIO, J.A. Análise química para avaliação da fertilidade de solos tropicais. Campinas: IAC, 2001. 285p.

SHUMAN, L.M. Effect of ionic strength and anions on zinc adsorption by two soils. Soil Science Society of America Journal, v.50, p.1438-1442, 1986.

SILVEIRA, M.L.A.; ALLEONI, L.R.F.; CASAGRANDE, J.C.; CAMARGO, O.A. Energia livre da reação da adsorção de cobre em Latossolos ácricos. Scientia Agricola, v.56, p.1117-1122, 1999.

SINGH, T.S.; PANT, K.K. Equilibrium, kinetics and thermodynamic studies for adsorption of As(III) on activated alumina. Separation and Purification Technology, v.36, p.139-147, 2004.

SOARES, M.R.; ALLEONI, L.R.F.; CASAGRANDE, J.C. Parâmetros termodinâmicos da reação de adsorção de boro em solos altamente intemperizados. Química Nova, v.28, p.1014-1022, 2005. SOIL SURVEY STAFF. Soil taxonomy: a basic system of soil classification for making and interpreting soil surveys. Washington: Government Printing Office, 1999. (Agriculture Handbook, 436).

SPOSITO, G. The chemistry of soils. New York: Oxford, 1984. $277 \mathrm{p}$.

TAKKAR, P.N.; WALKER, C.D. The distribution and correction of zinc deficiency. In: ROBSON, A.D. (Ed.). Zinc in soils and plants. Dordrecht: Kluwer Academic Publishers, 1993. p.151-165. WEBER, O.L. dos S.; CHITOLINA, J.C.; CAMARGO, O.A.; ALLEONI, L.R.F. Structural and variable electric charges of highly weathered tropical soils. Revista Brasileira de Ciência do Solo, v.29, p.867-873, 2005. 